\title{
"Aquela serra é o xapono deles": sobre encontros, ontologias e equivocidades no Projeto Yaripo
}

"That sierra is their xapono":

about encounters, ontologies and equivocations in the Yaripo Project

\section{Leon Terci Goulart}

\section{(2) OpenEdition Journals}

\section{Edição electrónica}

URL: http://journals.openedition.org/aa/6641

DOI: $10.4000 /$ aa. 6641

ISSN: 2357-738X

\section{Editora}

Programa de Pós-Graduação em Antropologia Social (UnB)

\section{Edição impressa}

Paginação: 85-105

ISSN: 0102-4302

\section{Refêrencia eletrónica}

Leon Terci Goulart, «"Aquela serra é o xapono deles":

sobre encontros, ontologias e equivocidades no Projeto Yaripo», Anuário Antropológico [Online], v.45 n.

3 | 2020, posto online no dia 16 setembro 2020, consultado o 27 abril 2021. URL: http://

journals.openedition.org/aa/6641 ; DOl: https://doi.org/10.4000/aa.6641

\section{(c) (i) (9)}

Anuário Antropológico is licensed under a Creative Commons Atribuição-Uso Não-Comercial-Proibição de realização de Obras Derivadas 4.0 International. 


\title{
“Aquela serra é o xapono deles": sobre encontros, ontologias e equivocidades no Projeto Yaripo
}

\author{
"That sierra is their xapono": \\ about encounters, ontologies and equivocations in the Yaripo Project
}

DOI: https://doi.org/10.4000/aa.6641

\section{Leon Terci Goulart • Universidade Federal de São Carlos - Brasil}

Mestre e Doutorando em Antropologia Social pelo Programa de Pós-Graduação em Antropologia Social da

Universidade Federal de São Carlos (PPGAS/UFSCar).

Este artigo explora como algumas categorias do discurso ambientalista podem ser acionadas pelos Yanomami de Maturacá (São Gabriel da Cachoeira, Amazonas) a partir de sua participação em um projeto de ecoturismo de base comunitária, uma vez que, além de representar uma nova fonte de renda, a proposta é vista por eles como um meio de combater o garimpo ilegal e de "proteger a natureza e a floresta". 0 Projeto Yaripo consiste em uma proposta de visitação turística à Terra Indígena Yanomami e ao Parque Nacional do Pico da Neblina, que conta, para além do envolvimento indígena, com o apoio do Instituto Socioambiental, da Fundação Nacional do Índio, do Instituto Chico Mendes de Conservação da Biodiversidade e do Exército Brasileiro. A hipótese central é que há neste cenário mais de uma forma de compreender os conceitos de "natureza", "floresta" e "território", isto é, os locais destinados à visitação turística, e que essas percepções díspares pautadas por pressupostos ontológicos distintos estão conectadas de algum modo. Pretende-se, assim, refletir como a noção de urihi, a floresta yanomami - um espaço cosmopolítico habitado por subjetividades não humanas -, aparece nesse arranjo, levando em conta as questões que me foram colocadas pelos Yanomami sobre algumas das implicações do trânsito por esses lugares - com ou sem a presença de visitantes -, bem como de seus desdobramentos na elaboração do projeto.
This article explores how some categories of the environmentalist discourse may be operated by the Yanomami of Maturacá (northwestern Brazilian Amazon) in their participation in the development of an ecotourism project. Since it represents more than just a source of income, the project is also seen by them as a way to combat the illegal mining activity and to "protect nature and the forest". The Yaripo Project consists in a touristic proposal within the indigenous territory and the limits of the National Park of Pico da Neblina, which counts, beyond the indigenous involvement, with the participation of Instituto Socioambiental, Fundação Nacional do Índio, Instituto Chico Mendes de Conservação da Biodiversidade and Brazilian Military. The central hypothesis here is that there is more than one way of perceiving the concepts of "nature", "forest" and "territory" - in other words, the places intended for touristic visitation - in this encounter between indigenous and non-indigenous agents, and that those different perceptions, constructed from distinct ontological assumptions, are connected in some way. Therefore, this research is intended to discuss how the concept of urihi, the yanomami forest - a cosmopolitical space inhabited by non-human subjectivities -, emerges in this scenario taking into consideration the matters pointed out by the Yanomami about the implications of transiting through this site, as well as its effects in the elaboration of the project. 


\section{Introdução}

Este artigo explora alguns dos modos pelos quais os Yanomami da região de Maturacá vêm operando categorias como "natureza”, "floresta” e "território" na implantação de um projeto de ecoturismo de base comunitária na Terra Indígena Yanomami e no Parque Nacional do Pico da Neblina, proposta que também conta com a participação do Instituto Socioambiental (ISA), da Fundação Nacional do Índio (FUNAI), do Instituto Chico Mendes de Conservação da Biodiversidade (ICMBio) e do Exército Brasileiro - os "parceiros", como se costuma dizer em Maturacá1. A hipótese central é que há neste cenário mais de uma forma de compreender tais conceitos, e que elas se conectam de algum modo. Por um lado, ao lançarem mão dessas categorias, os Yanomami mobilizam diversos aspectos de sua sociocosmologia, como o conceito de urihi, comumente traduzido como floresta, e a diversidade de seres não-humanos que habitam nesse espaço. De outra parte, por se tratar de uma área de sobreposição entre Terra indígena (TI) e Unidade de Conservação (UC), há diretrizes legais específicas que definem este território e que são pautadas por pressupostos ontológicos divergentes dos indígenas, também constantemente acionadas nos encontros entre os participantes do projeto. Busca-se, com base na literatura recente que trata da comunicação pela diferença (de la Cadena, 2015; Strathern, 2004; Viveiros de Castro, 2004a; 2015) - ou das relações entre sujeitos que compõem mundos díspares -, pensar essas percepções distintas acerca da floresta e da natureza como composições, isto é, explorá-las nos encontros entre os Yanomami e os parceiros, sem separá-las em unidades autônomas e isoladas.

Na primeira parte do texto, realizo uma breve apresentação sobre o povo Yanomami, em seus aspectos mais gerais, e a respeito de Maturacá, localidade situada no município de São Gabriel da Cachoeira, noroeste do estado do Amazonas. Ademais, a região apresenta uma particularidade que merece maior atenção: a mencionada sobreposição de duas figuras jurídicas distintas, que incitou o fechamento do parque para a visitação no início dos anos 2000. Em seguida, descrevo o Projeto Yaripo Ecoturismo Yanomami, proposta que deverá ser gerida pelas duas associações indígenas locais - a Associação Yanomami do Rio Cauaburis e Afluentes (AYRCA) e a Associação das Mulheres Yanomami Kumirãyõma (AMYK) -, com apoio do ISA, da FUNAI e do ICMBio. Assim, pretendo sintetizar o histórico do turismo no Yaripo, como é chamado o Pico da Neblina pelos Yanomami, desde os envolvimentos iniciais dos moradores da região com a atividade até a elaboração do projeto, cotejando os relatos locais com fontes bibliográficas a esse respeito.

Sem demora, pretendo explorar alguns dos entendimentos e expectativas locais relacionados ao turismo e à compreensão dos sítios destinados à visitação, ou seja, a floresta urihi e o Yaripo. Abordarei o conceito de urihi - um "espaço cosmopolítico" habitado por diversas subjetividades díspares (Sztutman, 2005), como os espíritos hekura - levando em conta as questões que me foram colocadas pelos Yanomami sobre algumas das implicações do trânsito por esses lugares - com ou sem a presença de visitantes -, bem como de seus desdobramentos na elaboração do Projeto Yaripo. De modo geral, não somente enquanto fonte de renda, os Yanomami e os parceiros também veem o projeto como um meio de "proteger
1 Trata-se de um tema anexo à minha pesquisa de mestrado, desenvolvida entre 2017 e 2020, que consistiu em uma etnografia centrada na participação dos Yanomami de Maturacá na elaboração e implantação do Projeto Yaripo (Goulart, 2020). Os dados aqui apresentados foram coletados durante as reuniões de planejamento do projeto de turismo do ano de 2018, que ocorreram em Maturacá - e contaram com a presença de todos os moradores envolvidos com o projeto e dos parceiros (ISA, ICMBio e FUNAI) -, bem como ao longo de minha permanência na região por dois meses após o término desses encontros. Agradeço ao Geraldo Andrello, pela orientação cuidadosa ao longo do desenvolvimento da pesquisa, e à Luisa Amador Fanaro, pela revisão deste texto. Também sou grato à comissão editorial e aos pareceristas do Anuário Antropológico pelas críticas, comentários e sugestões que visaram ao aprimoramento deste artigo. Todos os erros e imprecisões são de minha responsabilidade. 
a floresta" e de combater o garimpo ilegal na região, atividade exploratória que marca o histórico recente de relações entre esse povo e os não indígenas ${ }^{2}$. De mais a mais, é nos encontros com os "parceiros" que os moradores de Maturacá mobilizam algumas das categorias do discurso ambientalista, tal qual "floresta" e "natureza". Isto posto, como os Yanomami vêm operando tais conceitos? Como indígenas e não indígenas se fazem entender nesse palco marcado por "equivocidades” (Viveiros de Castro, 2004a; 2015)?

\section{Os Yanonami e o Projeto Yaripo}

O termo "Yanomami" remete a uma família linguística amazônica composta por ao menos quatro línguas (Sanima, Ninam, Yanõmami e Yanomam), sendo cada uma subdividida em diversos dialetos (Kopenawa; Albert, 2015, p. 553). Sua população total é de, aproximadamente, 38200 pessoas, sendo 26780 no Brasil (SESAI, 2019) e 11431 na Venezuela (INE, 2011). As comunidades Yanomami variam em população, disposição e formato das habitações, podendo ser constituídas por desde poucas dezenas de pessoas - em casas coletivas circulares ou retangulares - até por algumas centenas delas, morando em casas familiares arranjadas em formato circular ao redor de uma praça ou espaço central ${ }^{3}$. Yanonami (com "n" ao invés de "m") é o termo de autodesignação utilizado pelos moradores de Maturacá e sua grafia corresponde à que me foi indicada por meus interlocutores; já o idioma local constitui uma variação da língua Yanõmami. Assim, empregarei o termo "Yanonami" para me referir especificamente aos grupos que vivem às margens do canal Maturacá, e utilizarei a expressão "Yanomami" para designar esse povo em escala mais ampla.

"Maturacá" pode corresponder, tanto para quem é de fora como para os Yanomami, a um termo genérico para designar todas as "comunidades" (xapono) ${ }^{4}$ que se situam nas proximidades das margens do canal de mesmo nome e no sopé da Serra do Padre (Opota, em Yanonami), onde vivem cerca de 1700 pessoas (SESAI, 2017), compondo pouco mais de duzentos grupos domésticos (yahi). Há na região a presença da Missão Salesiana Nossa Senhora de Lourdes, desde 19545; do $5^{\circ}$ Pelotão Especial de Fronteiras, desde 1989; do Polo Base de Saúde de Maturacá, vinculado ao Distrito Sanitário Indígena Yanomami; e de três escolas da rede pública de ensino, sendo duas municipais e uma estadual. Segundo os Yanonami, as oito comunidades atuais (Maturacá, Ariabú, União, Auxiliadora, Beira-rio, Santa Maria, Vila Alta e Cupuaçu) se formaram a partir de sucessivas fissões de um único grupo que migrou, em meados dos anos 1950, das proximidades do igarapé Cuiabixi (Masiripiwëi), no sopé do Pico da Neblina, para o entorno da base missionária. Ademais, Menezes (2010) e Smiljanic (2002) apontam que a fundação da missão Nossa Senhora de Lourdes também constituiu um polo de atração para a incorporação, às comunidades mencionadas, de pequenos grupos circundantes. Assim, a composição atual de Maturacá decorre de divisões subsequentes de uma única comunidade de antepassados aliadas à absorção de outros grupos que ocupavam partes adjacentes do território.
2 Atualmente, estima-se que o garimpo ilegal na TI Yanomami envolva mais de vinte mil pessoas. Disponível em: https://www1.folha.uol.com.br/ poder/2019/05/invasao-em-terra-indigena-chega-a-20-mil-garimpeiros-diz-lider-ianomami. shtml. Acesso em: 26 maio 2020.

3 Não reproduzirei aqui uma extensa descrição histórica e etnográfica sobre esse povo indígena, já que existe uma ampla bibliografia a seu respeito. Dentre as mais relevantes aqui, vale mencionar Albert (1992, 2002), quanto ao histórico de contato e às relações com os brancos; a tese de doutorado do autor (Albert, 1985), que consiste em uma ampla etnografia sobre os Yanomami orientais (falantes da língua yanomam), sobre sua organização socioespacial, seu "sistema sociopolítico" e ritual; os trabalhos de Alès (1984, 1990), sobre a dinâmica e a fluidez da organização social yanomami, fundada por suas relações com diferentes formas de alteridades sócio-políticas; os trabalhos de Kelly (2003, 2005), que compreendem ricos estudos com os Yanomami do alto Orinoco, tendo como foco etnográfico suas relações com os brancos e com o sistema venezuelano de saúde; finalmente, sobre os Sanumá, ver também Ramos (1990) e Taylor (1972). Além disso, há a obra produzida em colaboração por Kopenawa e Albert (2015) que aborda, a partir da perspectiva do xamã yanomam, diversos aspectos de sua cosmologia e da relação com os não-indígenas. Sobre a região de Maturacá especificamente, embora as referências sejam mais recentes e restritas, vale mencionar o artigo de Smiljanic (2002), a tese de doutorado de Menezes (2010) e a dissertação de mestrado de Ferreira (2017).

4 Por "comunidades", refiro-me aos conjuntos de grupos domésticos adjacentes articulados por laços de parentesco cognático e relações de solidariedade.

5 A fundação da missão de Maturacá se insere no longo 


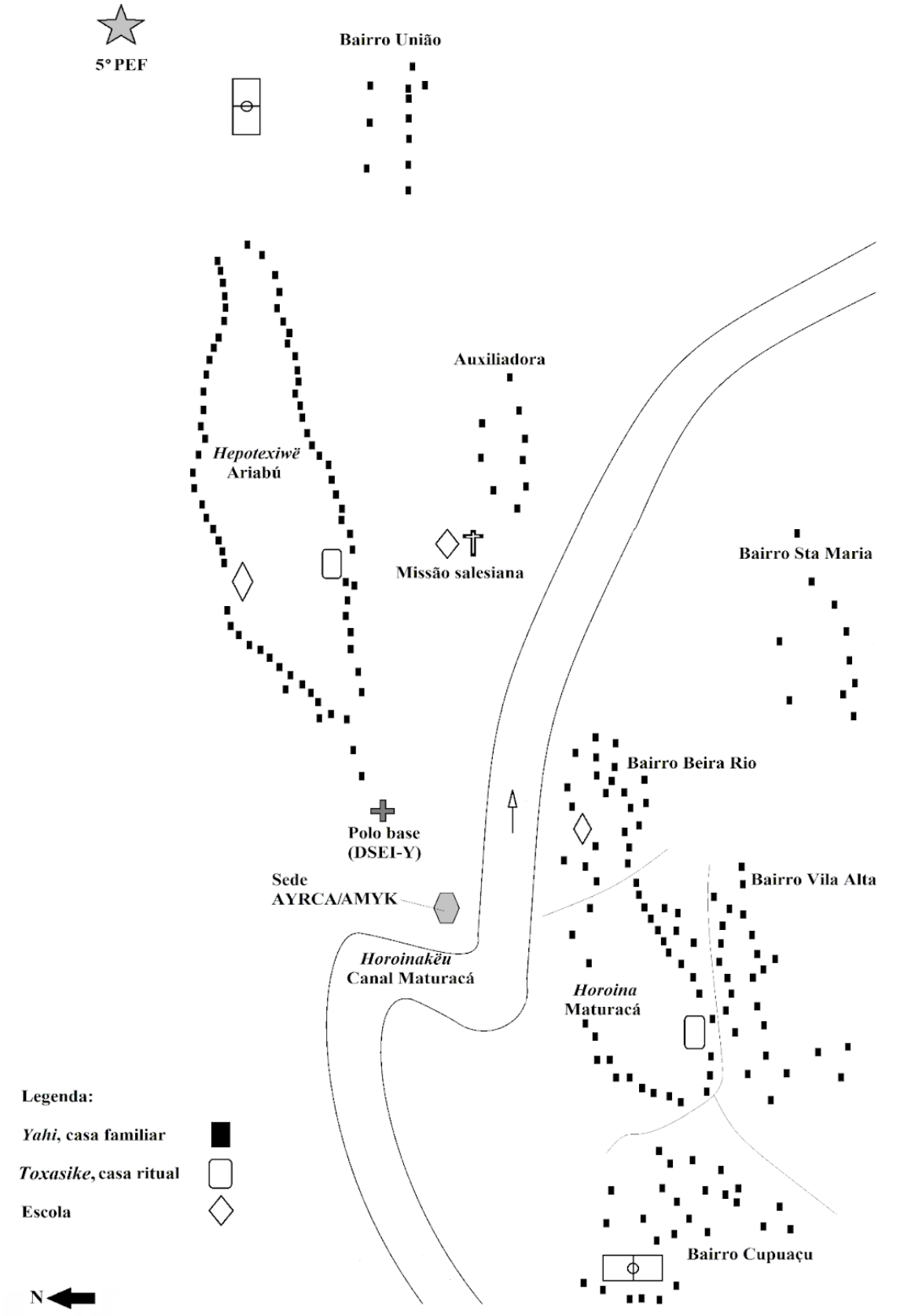

Figura 1: As comunidades de Maturacá. Fonte: elaborado pelo pesquisador.

Para além das transformações que se desdobraram a partir do longo convívio com os missionários (como a alta concentração populacional e o abandono das casas coletivas), alguns eventos que ocorreram nas últimas décadas do século XX resultaram na sobreposição mencionada anteriormente. A partir dos anos 1970, os projetos de desenvolvimento econômico da ditadura militar, alinhados ao Plano de Integração Nacional (PIN) ${ }^{6}$, dispuseram os Yanomami em zonas de contato acentuadas com a fronteira econômica regional: construção de estradas, fazendas, planos de colonização, e primeiros garimpos (Albert, 1992). Nesse contexto, constatou-se a presença de ecossistemas endêmicos à área do Pico da Neblina e o governo federal criou o Parque Nacional (PARNA), em junho de 1979 (decreto ${ }^{\circ}$ 83.550) - atualmente, sua diretriz jurídica é regulamentada pelo Sistema Nacional processo de estabelecimento dos salesianos na região do rio Negro descrito por Andrello (2006, p. 105-106).
6 O PIN foi criado no governo do general Emílio Médici, em 1970, (Decreto-Lei no 1.106) e tinha como objetivo promover a colonização e exploração econômica de áreas da região amazônica caracterizadas como "vazios demográficos". Para tanto, previa-se a construção de rodovias que conectassem o extremo norte ao restante do país, como a Perimetral Norte, a Transamazônica, a Cuiabá-Santarém e a BR-307, que liga São Gabriel da Cachoeira ao distrito de Cucuí. 
das Unidades de Conservação (SNUC). A Terra Indígena Yanomami, por sua vez, foi homologada em 1992, após um longo processo de luta pelo reconhecimento dos direitos territoriais desse povo, marcado por um quadro trágico de calamidade sanitária e degradação ambiental impulsionado pela invasão garimpeira, sobretudo a partir dos anos $1980^{7}$.

O garimpo ilegal é uma questão presente até hoje no cotidiano dos moradores de Maturacá: garimpeiros provenientes de diversas partes do Brasil acessam zonas de mineração na Venezuela através de deslocamentos (fluviais e terrestres) pela TI Yanomami. Desse modo, essas pessoas se locomovem clandestinamente pelos rios Cauaburis e Maturacá transportando seus mantimentos e ferramentas, além de percorrerem parte do trajeto que leva ao Pico da Neblina. De mais a mais, costumam se beneficiar da necessidade de renda dos Yanonami os contratando como carregadores. Destaco que, atualmente, os Yanonami se posicionam contra a atividade garimpeira em seu território, mesmo que ela represente, para alguns, a única fonte de renda possível ${ }^{8}$.

Mesmo com o reconhecimento da ocupação imemorial do território pelos Yanomami e a consequente homologação da TI como área contínua, ela se encontra sobreposta a um número considerável de UCs (Figura 2) - a região de Maturacá, por exemplo, também se situa dentro dos limites do Parque do Pico da Neblina. Essas duas figuras jurídicas podem ser contraditórias, já que detêm diferentes regulamentações e finalidades. No caso específico do PARNA, o art. 7, § $1^{\circ}$ da Lei n 9.985 o define como "Unidade de Proteção Integral”, cujo objetivo é "preservar a natureza, sendo admitido apenas o uso indireto de seus recursos naturais". Sua particularidade como Parque Nacional permite o "turismo ecológico", mas o art. 11 , $2^{\circ}$ anuncia que "a visitação pública está sujeita às normas e restrições estabelecidas no Plano de Manejo da unidade”. Assim, se por um lado os $\S 2^{\circ}$ e $4^{\circ}$ do art. 231 da Constituição de 1988 garantem, respectivamente, o usufruto exclusivo dos recursos naturais das Terras Indígenas por esses povos e direitos imprescritíveis sobre elas, mesmo que se tratem de sobreposições a Unidades de Conservação, por outro, a ausência até aquele momento do plano de manejo e de diretrizes legais quanto às atividades turísticas em território indígena resultaram na proibição, no ano de 2003, do turismo no PARNA do Pico da Neblina e na TI Yanomami.
7 Sobre a invasão garimpeira e o longo processo de demarcação da TI Yanomami, desde sua criação inicial no formato de "ilhas" separadas por Florestas Nacionais (FLONAS), ver Albert e Le Torneau (2004). Para um panorama geral quanto à complexidade da situação encontrada no noroeste dos estados do Amazonas e de Roraima, onde sete Terras Indígenas e 14 Unidades de conservação se encontram sobrepostas de maneira complexa, ver Ricardo e Andrello (2004).

8 Reunidos em assembleia geral da AYRCA no dia 27 de julho de 2019, os Yanonami mantiveram posicionamento unânime contra qualquer forma de mineração em seu território. Disponível em: https://ayrca. files.wordpress.com/2019/09/ ata-ayrca-atualizada.pdf. Acesso em: 25 maio 2020. 


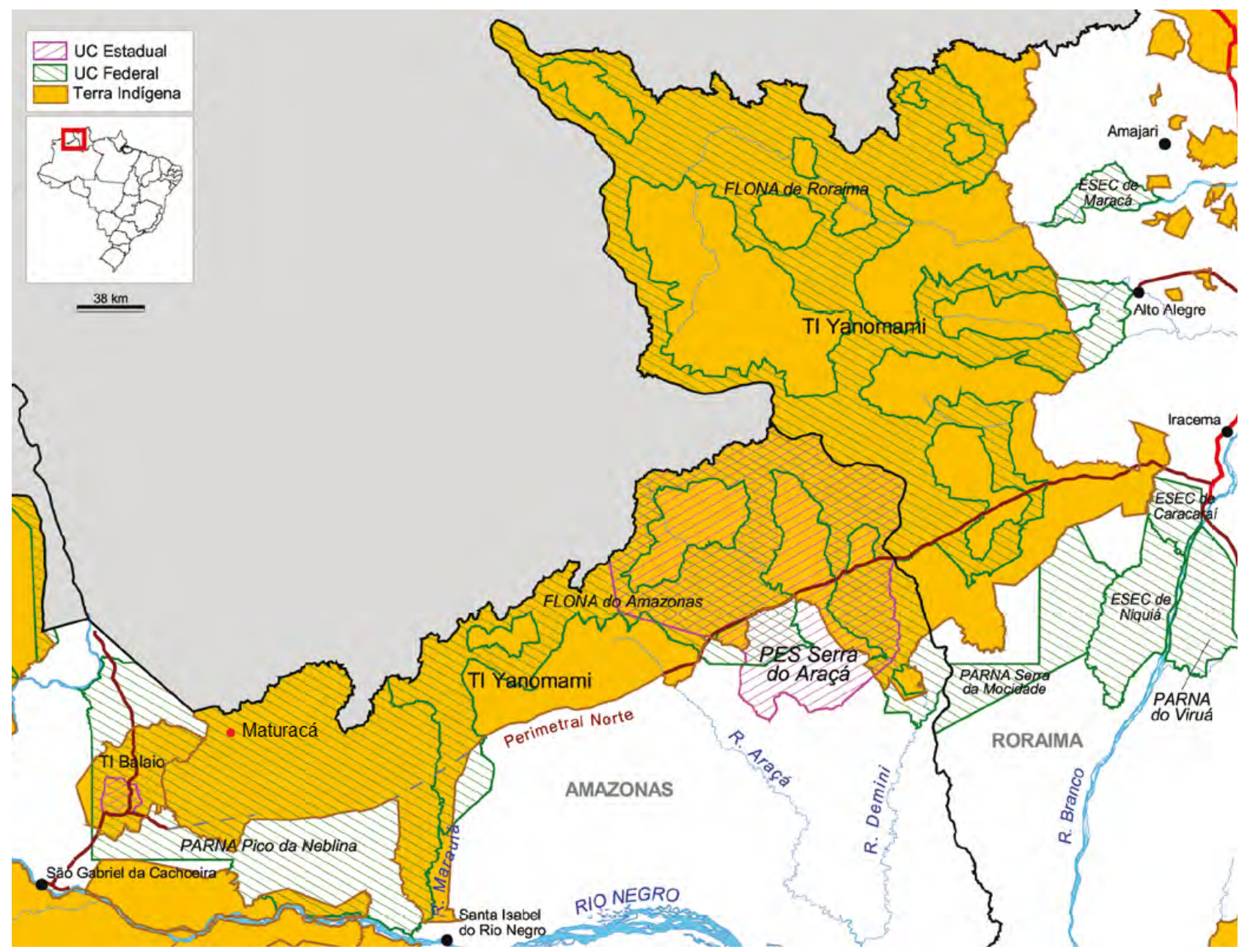

Yaripo (a "montanha do vento") é o nome dado pelos Yanonami ao Pico da Neblina, que consiste no ponto com a maior altitude em território brasileiro, com cerca de 2995 metros (IBGE, 2016). Devido a esta particularidade, bem como à presença de ecossistemas próprios à região, trata-se de um local com grande procura para a visitação turística, para a prática de trilhas, montanhismo e realização de pesquisas. Antes do fechamento do parque, no ano de 2003, a área recebia turistas sem o consentimento dos Yanonami, o que incitava, para além de possíveis conflitos, riscos de proliferação de doenças entre os moradores das comunidades que vivem dentro das imediações do PARNA (Smiljanic, 2004).

Em linhas gerais, por efeito da falta de fiscalização e regulamentação pelas entidades responsáveis, duas formas de turismo foram realizadas na região, do ponto de vista jurídico, desde a criação do Parque Nacional. A primeira delas é o turismo ilegal, praticado em território indígena sem o consentimento das comunidades, após o fechamento do parque, e devido à negligência ou conformidade das instituições fiscalizadoras (Exército, IBAMA, ICMBio e FUNAI); a segunda, por sua vez, é o turismo clandestino, realizado - embora sem consenso geral das comunidades - com o respaldo de alguns Yanonami, mas sem regulamentação por parte de agências administradoras do PARNA (IBAMA e ICMBio). Essa segunda forma de turismo principiou em meados dos anos 2000, quando alguns Yanonami
Figura 2: Terra Indígena Yanomami e PARNA Pico da Neblina. Localização aproximada de Maturacá: destaque do pesquisador Fonte: Ricardo (2004, p. 609). 
perceberam que essa atividade se apresentava como alternativa econômica ao garimpo e se envolveram diretamente com ela. Contudo, a discordância interna quanto à prática, as acusações em torno do uso indevido do nome da associação local (AYRCA) e a falta de repartição dos benefícios financeiros trouxeram conflitos internos à associação e às comunidades da região de Maturacá. A presença de visitantes indesejados também é tema presente no laudo antropológico elaborado por Coutinho Júnior (2013) ${ }^{9}$ : além de facilitar a entrada ilegal de visitantes, funcionários das instituições estatais também fizeram "vista grossa” para o acesso de membros da fronteira extrativista na região, como garimpeiros e madeireiros.

Em 2012, foi instituída a Política Nacional de Gestão Territorial e Ambiental em Terras Indígenas (PNGATI) ${ }^{10}$ e foi criado, conforme as normas desta, o Conselho Gestor do PARNA Pico da Neblina, composto por representantes da FUNAI, ICMBio, Exército e dos povos indígenas que habitam territórios sobrepostos ao parque, sendo quatro do povo Yanomami. Foi nesse contexto que Salomão, morador de Ariabú, foi indicado como um dos conselheiros do PARNA; com isso, segundo ele, os Yanonami puderam passar a se sentir um pouco mais inseridos na gestão de seu território junto às instituições estatais. Conforme Salomão, diante da participação yanonami̇ nesse conselho, foi debatida, no ano de 2012 e durante assembleia da AYRCA, a ideia de elaboração de um projeto de turismo para o Yaripo que pudesse ser gerido pelos Yanonami e se apresentar como uma alternativa econômica ao garimpo ilegal: "A ideia já era nossa, dos jovens serem capacitados para receber turistas; as lideranças já discutiam que o Yaripo era um benefício do povo yanonamí [...] o povo está crescendo demais, tem que gerar emprego para o povo ter uma vida melhor, a caça e a pesca ficaram muito difíceis" (Salomão Mendonça Ramos, abril de 2018).

Desde 2012, portanto, após os problemas vivenciados com o turismo ilegal e clandestino - no primeiro caso, a proliferação de doenças e, no segundo, associados à falta de repartição dos recursos provenientes da atividade -, os Yanonami buscaram, através da AYRCA, reunir parcerias e se adequar à regulamentação exigida para inaugurar uma forma legal de turismo em seu território, que pudesse trazer benefícios econômicos e ser gerido por eles. Em 2015, a FUNAI publicou a instrução normativa $\mathrm{n}^{\circ} 3$ (IN N $\left.{ }^{\circ} 03 / 2015\right)$, estabelecendo normas e diretrizes referentes ao turismo em Terra Indígena. Esta considera, dentre outros fatores, o apoio a iniciativas indígenas de turismo sustentável, já previstas na PNGATI. Além disso, também prevê que essas propostas deverão ser apresentadas mediante um Plano de Visitação, que deve ter como proponentes as comunidades indígenas ou suas organizações, permitindo o convite a parceiros públicos ou privados de seu interesse para sua execução e elaboração. Assim, do ponto de vista dos Yanonami, o projeto é de sua autoria e deles partiram os convites aos parceiros externos.

A partir de 2014 começaram, com efeito, as oficinas e procedimentos para a efetivação do Projeto Yaripo. O Plano de Visitação Yaripo já foi aprovado pelo ICMBio e teve anuência da FUNAI; a previsão para o início das atividades turísticas é 2021. A gestão do empreendimento e sua comercialização, para com pessoas físicas ou agências de turismo, deverão ser realizadas pelas associações AYRCA
9 Após o fechamento do PARNA em 2003, a Procuradoria Geral da República no Amazonas (PR/AM) promoveu uma audiência pública em São Gabriel da Cachoeira, na qual foi produzido um termo de acordo entre os Yanomami, IBAMA,

FUNAI e Exército que impunha à instituição responsável a elaboração do Plano de Manejo (cf. SNUC) da UC, bem como mantinha o fechamento do parque e condicionava sua abertura à elaboração do plano ou de um laudo pericial que atestasse a viabilidade e o consentimento do povo Yanomami em relação ao ecoturismo. Entretanto, em 2010 a AYRCA enviou um novo documento direcionado à PR/ AM, pedindo a "reativação do turismo consciente" e alegando que, embora tivessem sido favoráveis ao fechamento do parque em 2003, os Yanonami já haviam adquirido conhecimento sobre o que é o turismo e que a atividade era economicamente fundamental para as comunidades. Em face às reivindicações da AYRCA, a PR/AM solicitou a elaboração de um laudo antropológico para apurar a liberação do turismo na área. A partir dessa providência, foi iniciada, em 2010, a produção do laudo por Coutinho Júnior - publicado em 2013 (Coutinho Júnior, 2013, p. 8-10).

10 A PNGATI (Decreto no 7.747) garante "protagonismo e autonomia sociocultural dos povos indígenas, inclusive pelo fortalecimento de suas organizações, assegurando a participação indígena na governança da PNGATI, respeitadas as instâncias de representação indígenas e as perspectivas de gênero e geracional". $E$, ainda, "elaborar e implementar, com a participação dos povos indígenas e da FUNAI, planos conjuntos de administração das áreas de sobreposição das terras indígenas com unidades de conservação, garantida a gestão pelo órgão ambiental e respeitados os usos, costumes e tradições dos povos indígenas. [...] promover a participação indígena nos conselhos gestores 
e $\mathrm{AMYK}^{11}$. O turismo será realizado no formato de "expedições" e mediante a compra de pacotes para grupos compostos por desde duas até dez pessoas, compreendendo a estadia de dez dias em território yanomami, sendo dois para o percurso fluvial de ida e volta e oito para a trilha ao Pico da Neblina. Conforme lista divulgada na sede das associações, até a etapa que pude acompanhar em 2018, o Projeto Yaripo contava com o envolvimento direto de cerca de setenta e oito moradores das comunidades locais, que devem desempenhar os seguintes serviços: coordenador do projeto, auxiliar de expedição, guia, carregador de cume, carregador, carregador cozinheiro, cozinheira, piloto de barco, proeiro e comissão de recepção - cada expedição deverá incluir a participação direta de doze a dezoito Yanonamí, a depender do número de visitantes (cf. Plano de Visitação Yaripo, 2017).

Além de representar uma alternativa econômica ao garimpo ilegal, outras questões também emergiram em minhas conversas sobre o Projeto Yaripo com os Yanonami. Assim como nas reuniões com os parceiros, temas como "proteção à floresta" e "proteção do território" eram recorrentes. Conforme Salomão: "Esse projeto se tornou uma defesa pra a gente também. A gente tem que preservar esse parque que é tão belo e a montanha que é tão sagrada, eles merecem um projeto dos Yanonamí. É para o governo reconhecer que os Yanonami moram dentro do Parque Nacional”.

O que leva Salomão - bem como tantos outros com quem conversei em campo - a inferir que a montanha é "tão sagrada”? Disse-me Agostinho, morador de Maturacá, que o Yaripo compreende um espaço entendido como urihi, comumente traduzido como "floresta" ou "natureza" e habitado por uma miríade de espíritos, os hekura, de maneira análoga ao que afirmaram Kopenawa e Albert (2015, p. 476) sobre os xapiri. O que essas noções podem implicar aqui? Dados os limites desta pesquisa, a investigação que se segue não almeja esgotar o debate sobre o conceito de urihi, tanto em Maturacá como em outras realidades yanomami. Assim sendo, passemos a uma discussão sobre o tema levando em consideração os desdobramentos da percepção yanonami̇ de uma floresta socializada, por assim dizer, para a atividade turística, sem deixar de lado as diretrizes legais que também definem esse espaço e a comunicação interétnica no contexto do projeto.

\section{"Aquela serra é o xapono deles"}

Como já apontaram Albert (1985) e Alès (1984, 1990, 1995), a socialidade yanomami é notavelmente marcada pelo aspecto espacial. Sua organização social compreenderia uma dinâmica relacional entre as categorias de corresidentes, aliados e inimigos, que estariam dispostas no espaço na forma de círculos concêntricos, correlacionando a proximidade à convivialidade, à aliança e à redução da diferença; e a distância ao perigo, à inimizade e à agressão ${ }^{12}$. Tal dinâmica é atravessada pelas "relações sociopolíticas", que, por sua vez, são orientadas pela construção de alteridades conceituais articuladas às agressões xamânicas e às transações rituais (Albert, 1985, p. 190-191). Nesse sentido, cada “conjunto multicomunitário de aliados” é composto por um arranjo de diferentes grupos locais articulados por das unidades de conservação localizadas em áreas contíguas às terras indígenas".

11 Fundada em 1998, a Associação Yanomami do Rio Cauaburis e Afluentes (AYRCA) representa o conjunto das comunidades Yanonami de Maturacá, além das comunidades de Nazaré, Maiá e Inambu. Os principais mecanismos de mobilização da associação são encontros e reuniões semanais e/ou mensais -, bem como, especialmente, as assembleias anuais; não conta com funcionário remunerado e os trabalhos são realizados voluntariamente. No presente, os mandatos duram dois anos e as chapas são eleitas através de votação durante as assembleias (cf. Menezes, 2010, p. 190-225). Criada mais recentemente, em 2015, a Associação das Mulheres Yanomami Kumirãyõma (AMYK) foi idealizada, segundo a atual presidente, Floriza, a partir de sua experiência pessoal como primeira mulher a compor uma diretoria eleita da AYRCA e, consequentemente, ter estado em contato com o Departamento de Mulheres da Federação das Organizações Indígenas do Rio Negro (FOIRN). Embora tenha sido elaborada inicialmente para difundir o artesanato yanonami, a associação também é mobilizada como mecanismo de construção da visibilidade política das mulheres (cf. Ferreira, 2017, p. 84-138).

12 Em um trabalho de síntese, Viveiros de Castro (2017) apontou, mais recentemente, que essa lógica de diferenciação ternária - entre corresidentes, aliados e inimigos - constitui um aspecto geral do pensamento e socialidade ameríndios na Amazônia. 
trocas matrimoniais e cerimoniais, sendo formado após sucessivas fissões de uma comunidade inicial em um movimento centrífugo de reprodução social. Trata-se de um contexto no qual a concentração de relações de afinidade no interior do grupo local provoca sua cisão, originando novas unidades. Em suma, a organização social yanomami é baseada na parentela cognática e, desse modo, os conjuntos comunitários estariam em processo constante de recomposição, marcadamente influenciados pelas relações com o exterior (idem, 1985, p. 195).

A dinâmica de recomposição dos diferentes conjuntos comunitários implicaria, ainda, deslocamentos paulatinos pelo território, o que levaria cada grupo a se identificar com os lugares habitados e a distinguir seus integrantes a partir das comunidades das quais procedem seus ascendentes, e, portanto, a concepção yanomami de territorialidade estaria associada a esses movimentos (Alès, 1995, p. 211). Embora, entre os Yanonami, esse processo tenha sido transformado, uma vez que todas as comunidades se encontram próximas à base missionária, a recomposição dos grupos ainda ocorre na medida em que as comunidades têm sido, pouco a pouco, divididas, gerando novas unidades, desde meados dos anos 1990. Em Maturacá, todos os moradores das oito comunidades se reconhecem como Opotathëri, em referência à serra Opota, e qualificam parte de seus antepassados como Masiripiweëthëri, em menção ao igarapé Masiripiwë̈i, situado no sopé do Yaripo, local de morada de seus ascendentes antes da chegada dos missionários. Como sugeriu Alès (1995, p. 212), a enunciação de lugares antigos constitui um meio de identificação tanto da "genealogia" das comunidades como das genealogias de seus integrantes. Isto é, esse processo diz respeito à toponímia que estrutura a memória social de cada conjunto comunitário.

Não somente através dessa memória toponímica, alguns lugares também são conhecidos por meio das práticas xamanísticas. Como indicou Davi Kopenawa, "nós, Yanomami, quando queremos conhecer as coisas, esforçamo-nos para vê-las no sonho" (Kopenawa; Albert, 2015, p. 465). Nesses termos, mesmo os nomes de algumas dessas localidades são conhecidos nos sonhos ou viagens xamânicas, sendo contados pelos espíritos que lá vivem aos xamãs (cf. Chiappino, 2007), esses "viajantes por excelência” (Carneiro da Cunha, 1998, p. 12), que transmitem essa sabedoria às demais pessoas. Com o Pico da Neblina, não parece ser diferente: disse-me Salomão que lá é o local de morada de Yoyoma, uma mulher espírito que pode se apresentar aos pajés durante suas viagens, e que o nome Yaripo "saiu da boca dela".

De mais a mais, para os Yanonami, as fronteiras entre o que é de domínio humano e o que é não-humano parecem incidir sobre uma compreensão, de fato, espacial: as roças, por exemplo, que se localizam nos entornos próximos às comunidades, demarcam e demonstram as fronteiras entre o que é xapono e o que não é. Portanto, embora haja áreas adjacentes às comunidades ocupadas por mata densa, o espaço entendido por urihi começa somente após os limites definidos pelas roças familiares. De maneira similar, Lizot (2004, p. 445) definiu urihi como "selva", isto é, todo espaço que não é compreendido pelas casas coletivas ou pelas roças. Assim, tal qual o gradiente de alteridades yanomam, as bordas que circunscrevem 
o que é urihi e xapono - humano e não-humano - também parecem compreender uma dimensão mais que (ou outra que) geográfica do território (Albert, 1985, p. 190). Nesses termos, se as comunidades são habitadas pelos Yanonamí, a floresta é o local de morada de uma miríade de sujeitos não-humanos - os animais, plantas e os espíritos hekura, sendo estes não visíveis aos olhos de todos. As relações com essas subjetividades são mediadas pelos "pajés"13, também chamados hekura, através dos diálogos hekuramou, quer dizer, por meio do xamanismo yanonami̇ e da inalação da epena, yãkoana para os Yanomam ${ }^{14}$.

A ideia de uma natureza socializada não é novidade no contexto amazônico e o alargamento da condição de sujeito para os não-humanos serviu de base para a formulação das teorias do animismo (Descola, 1992, 2006) e do perspectivismo ameríndio (Lima, 1996; Viveiros de Castro, 1996). Considero a segunda mais pertinente para os fins aqui propostos. O conceito de perspectivismo ameríndio, sintetizado para a Amazônia, consistiria em um modo de apercepção: “os animais e outros não-humanos dotados de alma 'se veem como' pessoas, e portanto, em condições ou contextos determinados, 'são' pessoas, isto é, são entidades complexas com estrutura de dupla face” (Viveiros de Castro, 2015, p. 43-44). Nesses termos, para Viveiros de Castro (1996, 2015, 2017), as cosmologias indígenas seriam pautadas por ontologias "multinaturalistas": humanos são aqueles que podem ocupar a posição de "sujeitos cosmológicos", uma vez que a diferença entre os seres do cosmos se dá no corpo - que aqui não é pensado somente sob um viés anatômico ou fisiológico, mas como um conjunto de afecções, que compõem um habitus. $\mathrm{O}$ que vale reter aqui é a ideia de uma unidade subjetiva que se estende aos não-humanos, ao passo que a particularização se dá no corpo - o lugar das perspectivas diferenciantes (Idem, 2015).

Os hekura que habitam a floresta yanonami moram nas serras e montanhas, que são, do seu ponto de vista, “como comunidades”. Conforme Agostinho, “[eles] moram nas serras, na visão deles seria uma casa deles né. Aquela serra ou aquela montanha é onde eles moram, é igual como esse xapono aqui [aponta em direção à comunidade de Maturacá], aquela serra é o xapono deles”. Da perspectiva desses seres, as montanhas são, segundo me relataram, habitações toxakesi (como as dos antepassados dos meus interlocutores, são casas multifamiliares), e só podem ser vistas da mesma forma - ou seja, do ponto de vista dos espíritos, como casas - pelos Yanonami que também são hekura, durante estado de transe ou em seus sonhos. A descrição fornecida por Agostinho vai também ao encontro do que afirmaram Kopenawa e Albert (2015, p. 118), ou seja, que as montanhas, serras e morros são casas para os espíritos xapiri que vêm aos xamãs - os montes são a sua morada, onde vivem multidões deles - e que a floresta não é vazia. Segundo Xavier, morador de Ariabú e à época presidente da AYRCA, o Yaripo "é a casa de todos os espíritos dos pajés, de todo mundo. Esse daí já é o central, é igual Brasília! Brasília não é central? O Yaripo também é central; é um xapono grande”. E, conforme Agostinho, o Yaripo "é um lugar sagrado, por isso que lá é o lugar dos pajés”. Assim, ao dizerem que o Pico da Neblina é um local sagrado, os Yanonami fazem referência a uma casa de espíritos vista como tal somente pelos pajés, e de
13 Opto pelo uso do termo "pajé" em vez de "xamã" por ser a expressão corrente entre os Yanonami quando fazem uso do português.

14 Por uma questão de espaço, não discutirei o xamanismo yanomami em profundidade. Sobre o tema, de modo geral, ver Kopenawa e Albert (2015: 88-192) e Jokic (2006, 2008). A respeito da articulação entre a atividade xamanística e o arranjo das alteridades sócio-políticas, ver também Albert (1985: 236-339), sobre os Yanomam; Alès (1995: 208-210), quanto aos Yanomami do alto Orinoco; e Taylor (1979, 1996), a respeito dos Sanumá. Acerca da ação dos espíritos auxiliares na "cura xamânica", ver Chiappino (2003). 
onde vêm alguns dos espíritos com os quais se comunicam nas práticas xamanísticas - tal como verificou Chiappino (2007, p. 376) entre os Yanomami da região da serra Parima. Ademais, é interessante notar que para descrever esse local, os Yanonami o fazem com menções aos seres que lá vivem.

Ainda sobre os espíritos, Agostinho me disse: "são gente, os espíritos, se chama hekura"; e completou: "não são yanonami que morreram, eles são outros; só quando eu for preparado eu consigo ver; só aquele que é preparado que tá vendo na visão dele" ${ }^{15}$. Conforme Xavier, uma pessoa não "preparada" que estiver caçando ou caminhando sozinha pela floresta pode escutar a voz dos espíritos, o que se apresenta como algo perigoso, pois se ela ficar com medo, pode "ser dominada, vai adoecer e morrer". Nesse sentido, embora alguns hekura se apresentem como auxiliares dos pajés, o encontro com outros desses seres, por pessoas não preparadas em momentos e espaços impróprios, pode se apresentar como grande risco aos Yanonami.

Há ainda outros espíritos que habitam a floresta yanonami, os haprapi: "mais poderosos e perigosos" e "donos dos animais da floresta" - como me disseram Agostinho e Lucilene, também moradora de Maturacá. Esses seres parecem remeter às imagens dos animais mitológicos yanomam descritos por Kopenawa e Albert (2015, p. 116-118), que são também xapiri e aos quais os animais "imitam" e são como "fotografias", quer dizer, essas imagens - utupë - seriam a "forma mítica primordial" dos animais (Idem, 2015, p. 621) ${ }^{16}$. Junior, morador da comunidade de Maturacá, me relatou que os haprapi só são vistos em sua "forma espiritual" pelos pajés durante as práticas de xamanismo, enquanto que aos olhos das "pessoas comuns", assumem sua "forma animal" - narrativa semelhante à de Kopenawa e Albert (2015, p. 117). Segundo a descrição dos meus interlocutores, os haprapi são, pois, parimi (imortais ou eternos), "maiores" e mais belos que os animais de caça. Disse-me Junior que esses donos espirituais são também hekura, mas são chamados mais comumente por haprapi quando se fazem "espíritos maus". Portanto, hekura quando auxiliares dos pajés e haprapi quando praticam atos maléficos, tudo a depender da experiência. Isto posto, essa flutuação parece remeter à eloquente proposta de Viveiros de Castro (2006, p. 326) em seu artigo sobre os xapiri (termo utilizado pelos Yanomam), quando o autor destacou a limitação conceitual da noção ocidental de "espírito" para tratar desse conceito no contexto amazônico, o qual não faria referência a categorias de caráter taxonômico, e sim a modos relacionais.

Sobre os atos maléficos praticados pelos espíritos, pude registrar que podem acontecer durante experiências de caça e após ocorrer uma forma de "insulto"17 ao animal presa. Conforme me explicou Lucilene, a "quebra de etiqueta" (Almeida, 2013) relacionada à caça ocorre, por exemplo, se o caçador mata animais em demasia e com grande frequência, ou, ainda, se vende sua carne. Conforme Kopenawa e Albert (2015, p. 474), a falta de generosidade do caçador na partilha da carne também pode conformar um tipo de insulto à caça. Para os Yanonami, algumas espécies de animais da floresta (queixadas, antas, pacas e macacos foram seus exemplos) possuem "donos"18, e é por isso que não se pode insultá-los
15 "Preparado" indica que somente os pajés ou pessoas orientadas por eles conseguem ver esses seres, durante o estado de transe provocado pela inalação da epena ou através dos sonhos.

16 Para os Yanomam, Kopenawa e Albert (2015) apontam que todos os animais da floresta possuem uma imagem mítica - yarori -, ao passo que os animais de caça (atuais) são como simulacros dessas imagens. Na narrativa de Davi Kopenawa, os animais atuais são ex-humanos - antepassados dos humanos atuais - que se metamorfosearam em caça no tempo mítico. As imagens vistas pelos xamãs na forma de espíritos xapiri, por sua vez, não correspondem aos animais atuais, e sim a seus ancestrais mitológicos. Tratar-se-ia de uma "triangulação ontológica" entre ancestrais animais, animais de caça e imagens xamânicas, elemento fundamental na cosmologia yanomam (Kopenawa; Albert, 2015, p. 621). Sobre o conceito de utupë, a "imagem" yanomami, ver também Albert (2014) e Valentim (2018, p. 213-238).

17 Segundo Mauro Almeida (2013, p. 15), o “insulto" é a "quebra de etiqueta no trato com o corpo do animal". Em seu contexto de pesquisa, no alto Juruá, o insulto pode ocorrer no transporte da caça ainda na floresta, no preparo da carne e no seu consumo por pessoas - humanas ou não - que não deveriam fazê-lo.

18 Certamente, a relação entre os animais e seus donos espirituais não evoca aqui a ideia de propriedade privada. O emprego do termo "dono" pelos Yanonami parece remeter à relação de domínio-maestria sintetizada por Fausto (2008). Segundo o autor, o conceito de dono-mestre é um modo relacional assimétrico que se aplica em diversos contextos: nas relações entre xamãs e seus espíritos auxiliares, entre humanos e xerimbabos e nas relações internas ao mundo não-humano. Tratar-se-ia também de uma forma de englobamento: 
durante a caça. $O$ insulto pode envolver aqui, portanto, uma retaliação conduzida pelo "espírito dono" (haprapi) do animal, que não ocorre de imediato: o caçador se expõe ao perigo quando volta à floresta e, sobretudo, quando se encontra sozinho. Nesses casos, a pessoa pode ser transformada em espírito - ou mesmo animal - e levada para morar com eles.

Durante minha estadia em Maturacá, um jovem yanonami̇ desapareceu na floresta quando saiu em perseguição a um grupo de porcos-do-mato (warë) e se perdeu de seu cunhado durante uma caçada. A compreensão dos Yanonami sobre esse evento foi a de que o jovem abateu uma grande quantidade de porcos em um curto período de tempo, além de ter comercializado a carne desses animais com pessoas de outras comunidades, e foi, portanto, transformado em espírito-queixada pelo "dono dos porcos", um haprapi. Após alguns dias sumido na floresta e a realização de vários contatos dos pajés com os hekura, o jovem foi encontrado por outro grupo de caçadores. Em outros termos, se a pessoa é "encantada", como dizem os Yanonami, ela passa a viver e a se comportar como o animal - andar, comer e se comunicar -, podendo se casar no interior do novo grupo e, portanto, se tornar um deles. Tal como afirmou Viveiros de Castro (2015), a distinção entre humanos e animais não parece ser aqui pensada a partir da fisiologia corporal, e sim das afecções, do conjunto de modos de ser que constituem as distinções implicadas na corporalidade.

Nesse sentido, o Yaripo em si era uma localidade pouco frequentada devido à possibilidade de inflexão de um "plano cósmico" (Sztutman, 2005), isto é, dada a intensa presença de agentes "sobrenaturais". Os Yanonami caçam e coletam alimentos apenas em alguns lugares nos entornos da serra do Imeri, onde se localiza o Pico da Neblina. No entanto, desde que se receba proteção dos pajés, o aumento do trânsito humano pelo Yaripo por conta do projeto de ecoturismo não me foi apresentado, em nenhum momento, como um problema. Por outro lado, se a frequência de deslocamentos por tais espaços se intensificou, é possível que o trabalho dos pajés também tenha passado a ser mais requisitado. A título de exemplo, durante minha estadia em Maturacá, houve um episódio em que Agostinho e Edivaldo, seu cunhado, tiveram que percorrer boa parte da trilha que leva ao Pico da Neblina para recolher alguns equipamentos usados na última expedição que ainda se encontravam por lá e para realizar manutenção em um dos acampamentos. Nessa ocasião, perguntei a Agostinho se mesmo desacompanhados pelos napë-termo pelo qual se referem aos brancos - eles careciam de conversar e pedir assistência a um pajé. Ele me respondeu que sim, pois "sempre tem que ir protegido”. Marcos Wesley, principal responsável do ISA na implantação do projeto, também me relatou que em julho de 2018, durante outra expedição técnica ao Yaripo, um servidor da FUNAI adoeceu e a preocupação dos Yanonami se voltou para a exigência de maior proteção aos pajés. Tal como verificou Taylor (1979, p. 204-205) entre os Sanumá, a atividade xamanística pode ser também praticada para afastar "espíritos maus" - geralmente associados à causa de doenças, ou mesmo de mortes -, seja devido à presença destes nas vizinhanças das comunidades ou para deslocamentos pela floresta. "o mestre é, assim, a forma pela qual uma pluralidade aparece como singularidade para outros" (Fausto, 2008, p. 334), ou seja, ele contém uma espécie. 0 dono-mestre seria, pois, uma singularidade magnificada e, ainda, consistiria em uma figura dupla: um protetor para seus filhos-xerimbabos e um afim predador para as outras espécies. Todavia, uma interpretação do haprapi yanonami enquanto dono-mestre requer uma maior investigação da relação desses espíritos com os animais de caça. 
Portanto, no Projeto Yaripo, as práticas que compreendem o trato com os hekura afloraram como uma preocupação dos próprios Yanonami para o trânsito pela região do Pico da Neblina. Ou seja, a preocupação recai, aqui, em como enfrentar os perigos - como o caso já mencionado do encantamento, em que um jovem foi transformado por um espírito-queixada durante uma caçada, mas que também pode ocorrer na circulação em locais perigosos - implicados pelos deslocamentos em lugares destinados ao turismo, sobretudo, com a presença de forasteiros despreparados. Para tanto, segundo Agostinho, “o guia que vai levar eles [os turistas] tem que conversar com o pajé e pedir proteção”. "Proteção” não somente ao guia yanonamí, mas também aos visitantes. Em Maturacá, nesses casos, ainda de acordo com Agostinho, os pajés fazem seus trabalhos no próprio xapono e, assim, é difícil saber qual contato os visitantes terão com tais práticas, posto que a visitação às comunidades não está prevista.

Durante a elaboração do Projeto Yaripo, em reuniões e expedições que antecederam minha estadia em Maturacá, as preocupações destacadas pelos Yanonami para o trânsito pela floresta também tiveram alguns desdobramentos no formato das futuras visitas. $O$ percurso seguido pelas trilhas, por exemplo, foi decidido conjuntamente entre os parceiros e os Yanonami, a fim de ser delineado nos locais considerados mais seguros por estes - segurança que diz respeito tanto à condição física do terreno quanto à presença dos hekura. Ademais, o cuidado exigido aos forasteiros motivou a criação de um "Manual de Conduta”, cuja versão reduzida se encontra anexa ao Plano de Visitação (2017, p. 49), tendo como uma das orientações a atenção às instruções fornecidas pelos guias e carregadores. Nesse sentido, disse-me Agostinho, um dos quatro guias yanonami, que alguns locais do Pico da Neblina não devem ser frequentados devido à presença de "espíritos maus" - alertou-me ele que o deslocamento por esses lugares, assim como a subida ao Yaripo sem a devida proteção dos pajés para afastar os hekura, pode ensejar o adoecimento e mesmo a morte de uma pessoa.

O intuito dessa pequena exposição foi apresentar o conceito de urihi e o Yaripo enquanto "espaços cosmopolíticos" (Sztutman, 2005), evidenciando os agentes sobrenaturais que neles habitam e indicando que as relações desempenhadas com e nesses sítios são comumente entendidas sob a lógica xamânica que, por sua vez, parece ser pautada pelo perspectivismo. Passemos agora a investigar como essas noções incidem nas relações dos Yanonami com os parceiros do Projeto Yaripo e no entendimento local sobre as diretrizes jurídicas (Terra Indígena e Unidade de Conservação) que definem os espaços destinados ao turismo. Em outras palavras, dadas as inflexões cosmopolíticas da noção yanonami̇ de urihi, quando e de que modo categorias como "floresta", "território" e "natureza” são acionadas nesse contexto? Se os Yanonami as empregam, quais sentidos lhes atribuem?

\section{(Des)Encontros e conexões}

As reuniões de planejamento do Projeto Yaripo do ano de 2018, que contaram com a presença de diversos "parceiros” (ISA, ICMBio e FUNAI), foram também pautadas por um discurso ambientalista. Explicações sobre categorias como "Uni- 
dade de Conservação", "Parque Nacional” e "Sistema Nacional de Unidades de Conservação" foram espalhadas pelos parceiros em lousas e cartazes na sede das associações. Suas falas também enfatizavam o papel preservacionista do projeto de turismo e destacavam que o garimpo ilegal era o principal vilão nesse sentido. Como ouvi diversas vezes dos parceiros, o projeto compreendido por uma gestão compartilhada da região sobreposta, tal qual previsto na PNGATI, tem como principal propósito a percepção da área sob o efeito de uma dupla proteção territorial, buscando destituir as contradições implicadas pelas diretrizes legais que regulamentam o conceito de Unidade de Conservação e Terra Indígena, mencionadas no início deste artigo. Os discursos proferidos pelos Yanonami, por sua vez, também traziam à tona categorias como "natureza" e "meio ambiente", como pode ser visto no depoimento de Marcos Figueiredo, professor yanonami e então membro da diretoria da AYRCA, registrado em uma dessas ocasiões:

“É um projeto limpo que não vai poluir o meio ambiente, não vai poluir os rios. É um projeto que vai proteger a natureza. Vai proteger a beleza que o Pico da Neblina oferece para as pessoas. Nossa expectativa é trazer pessoas para visitar, e não pessoas que destroem a beleza da natureza" (Marcos Figueiredo, março de 2018).

O garimpo também era condenado pelos Yanonami a partir da articulação de termos semelhantes. Disse Agostinho, por exemplo, que "[o garimpo] é a exploração de nossa terra e dos Yanonami”; Rene da Cruz Pinto, morador de Maturacá, por sua vez, enunciou que "o garimpo prejudica nossa natureza”. Após o termino das reuniões, ao tentar buscar, junto aos meus interlocutores, possíveis correspondências para os termos "natureza", "meio ambiente”, "floresta”, "paisagem" e "território" na língua yanonami, todos me foram traduzidos como urihi. Uma tradução para "turista”, que me foi dada por Salomão, também pareceu interessante: urihi mirewë, cuja tradução literal, segundo ele, seria "[quem] gosta de ver paisagens bonitas”, ou “[quem] gosta de ver a floresta”19. Além disso, segundo Floriza, um dos requisitos para que um Yanonami possa vir a participar e trabalhar no Projeto Yaripo é que ele "saiba sobre a natureza", tanto no que diz respeito à locomoção pela floresta quanto para orientar e contar histórias aos visitantes. Vale reter aqui que a geração envolvida mais diretamente com o projeto - no geral, os membros das associações, pessoas na faixa dos quarenta e cinquenta anos, como Floriza, Salomão, Xavier e Marcos Figueiredo - passou a acionar, nas reuniões e nas conversas junto a mim, os conceitos usados pelos parceiros.

Diante disso, o cenário aqui descrito parece apontar para duas abordagens que, como veremos, se conectam de alguma forma. Primeiramente, há que se levar em conta a apropriação estratégica feita pelos Yanonamì do discurso ambientalista. Em segundo lugar, deve-se assinalar que o propósito de preservação da floresta e do território possui aqui mais de um sentido, uma vez que o conceito de urihi privilegia, como vimos, a socialização da natureza e o naturalismo multiculturalista, que orienta nossa noção de meio ambiente, privilegia sua objetivação, tal qual já
19 Conforme Lizot (2004), o termo mi pode corresponder ao verbo "olhar" e rewë, por sua vez, consiste em uma partícula substantivizadora (no espanhol, "sustantivizador"). 
foi amplamente destacado (cf. Descola, 2006; Ingold, 2000; Latour, 1994; Viveiros de Castro, 2004b, 2015, 2017). Comecemos com a primeira abordagem.

Como já apontaram, entre outros autores, Carneiro da Cunha e Almeida (2017) e Albert (2002), nos encontros entre populações tradicionais ou povos indígenas com linguagens e projetos conservacionistas, diferentes sentidos podem ser atribuídos a suas categorias, assim como múltiplos efeitos podem ser produzidos. Por um lado, como sugeriu Carneiro da Cunha (2017), tal qual ocorreu com o conceito de "cultura", a apropriação indígena das categorias de "natureza", "meio ambiente" e "floresta" faz parte de um movimento de "ida e volta", isto é, tais noções chegam aos povos indígenas por intermédio de agentes externos (como antropólogos, funcionários de instituições estatais e membros de ONGs) e são transformadas por aqueles, retornando a nós com outros sentidos - como vimos, ao acionarem tais categorias, os Yanonami mobilizam o conceito de urihi e, com ele, toda uma gama de agentes sobrenaturais. Como sugeriram Kopenawa e Albert (2015, p. 476), "a verdadeira natureza é tanto a floresta como as multidões de xapiri seus habitantes”, afirmação que parece também ser expressa pelos Yanonamì sobre a floresta, o Yaripo e os hekura.

De outra parte, há uma motivação política e estratégica na apropriação desse discurso. Conforme Albert (2002), no contexto da demarcação da TI Yanomami, Davi Kopenawa encontrou, nos discursos ambientalistas e indigenistas, um engenhoso dispositivo de tradução cultural para a luta política pelos direitos de seu povo. Em escala diferente, os moradores de Maturacá parecem traçar um caminho semelhante: ao mobilizar, junto aos membros das instituições fiscalizadoras da TI e do PARNA, categorias e imperativos que alinham sua motivação com o propósito desses parceiros, os Yanonami, por meio de suas associações, almejam conquistar aliados não somente para obter uma fonte constante de renda, mas também para combater o garimpo ilegal e aprimorar a fiscalização de seu território contra esta ameaça. Declarações como "o Yaripo é um lugar sagrado", "o projeto vai proteger a natureza" e "o garimpo é a exploração da nossa terra" parecem ilustrar o reconhecimento da potência dessas alianças. Vale lembrar que os moradores de Maturacá já se envolvem com o turismo há pelo menos dez anos, que eles mantêm um "representante" no conselho gestor do PARNA desde 2012, que o desenvolvimento do projeto principiou em 2014 e que, nesse intervalo, os membros da AYRCA e da AMYK participaram de oficinas previstas na PNGATI. Afinal, como afirmou Salomão, o projeto também se tornou uma "defesa" para os Yanonami; o parque, que é "tão belo", e a montanha, que é "tão sagrada", "merecem um projeto".

De mais a mais, parece-me que esse diálogo entre os Yanonami e os parceiros, pautado pela "proteção à natureza", estava marcado por "equivocidades" (Viveiros de Castro, 2004a; 2015), ou seja, por uma comunicação pela diferença, em que práticas ou conceitos são pensados a partir de pontos de vista ontologicamente distintos. Em outros termos, pode-se pensar as categorias de "natureza" e "floresta" nesses encontros entre os Yanonami e os parceiros na chave das "conexões parciais" (Strathern, 2004), conceito proposto a partir do diálogo com as noções do "ciborgue" (cf. Haraway, 2009) e da "pessoa fractal" (cf. Wagner, 1991). Em li- 
nhas muito gerais, tal recurso conceitual constitui uma ferramenta analítica-metodológica para pensar as interações entre diferentes mundos - a relação com o "outro" - como modos relacionais. Isso implicaria compreender práticas que conectam ontologias distintas como composições, sem separá-las em unidades isoladas e totalizantes, quer dizer, sujeitos e coletivos emergem das relações e não apenas as constituem hierarquicamente como partes de um todo. Conforme de la Cadena (2015, p. 31-33), a noção de conexões parciais permite pensar como práticas indígenas e não indígenas aparecem umas nas outras e, ao mesmo tempo, permanecem distintas: são "mais que uma e menos que muitas" ${ }^{20}$ - nem unidades e nem fragmentos isolados, elas emergem na relação. Em suma, para esta autora, a potencialidade dos conceitos de "conexões parciais" e de "equivocidade" reside em permitir abordagens que, a um só tempo, tratem desses encontros sem definir seus sujeitos separadamente e se afastem de pensar as práticas e os conceitos que deles emergem enquanto hibridismos.

O argumento aqui é que, nesses encontros potencializados pelo Projeto Yaripo, o imperativo de combater o garimpo está associado ao de "proteger a floresta", movimento que conecta a ideia de urihi à nossa noção de natureza, de forma a constituir uma composição: há aqui "mais que um e menos que muitos" (de la Cadena, 2015) desses conceitos, que formam um emaranhado do qual não se consegue captar seus elementos separadamente. O PARNA do Pico da Neblina, vale lembrar, é uma Unidade de Conservação, definida conforme a Lei 9.985 enquanto "espaço territorial e seus recursos ambientais [...] com objetivos de conservação e limites definidos". Já o conceito de "conservação da natureza" é delineado pela mesma regulamentação com a finalidade de "restauração e a recuperação do ambiente natural". Ademais, a UC em questão é uma Unidade de Proteção Integral, que tem como objetivo a "manutenção dos ecossistemas livres de alterações causadas por interferência humana". Certamente, essas definições fundamentadas a partir de uma ontologia "naturalista", que trata a natureza como um domínio exterior ao humano, como uma realidade objetivada (Descola, 2006, p. 146), não compreendem o conceito yanonami de urihi, tal qual discutido anteriormente. Todavia, levando em conta os argumentos de Strathern (2004), de Viveiros de Castro (2004a, 2015) e de la Cadena (2015), essas duas formas de pensar a floresta, a natureza e o território não estão aqui desconectadas uma da outra.

Nesse sentido, Mauro Almeida (2013, p. 17) sugeriu pensar a "conexão entre a experiência e o mundo da ontologia" como um "encontro pragmático". Decerto, os encontros possíveis a partir da experiência yanonamiz e sua ontologia "multinaturalista" com as diversas subjetividades - animais e sobrenaturais - que habitam a urihi não são os mesmos praticados desde uma ontologia "naturalista" - preeminente nas legislações que regulamentam a relação das agências ambientais estatais com a "natureza" - e sua experiência em uma floresta desprovida de intencionalidade: "[há] diferentes realidades em competição, junto com ontologias que nesse caso são antagônicas" (Idem, 2013, p. 21). Entretanto, há uma regra comum nesse palco de multiplicidade ontológica: a(s) floresta(s) deve(m) ser protegida(s), seja para cuidar de toda uma rede de relações e "intercâmbios cosmológicos" com di-
20 No original, "more than one less than many" (de la Cadena, 2015, p. xxvii). 
versos seres (Albert, 2002, p. 248), ou para preservar ecossistemas próprios à região.

Como vimos, nas reuniões de planejamento do Projeto Yaripo, um tema comum presente nas falas de todas as partes era a atividade garimpeira como prejudicial à floresta e incompatível com uma proposta de ecoturismo. Além disso, um dos objetivos contidos no Plano de Visitação Yaripo (2017, p. 17) - elaborado em colaboração pelos Yanonami e pelos parceiros - consiste em "proteger a urihi [...] apresentando o ecoturismo ao Yaripo como alternativa ao garimpo de ouro". Embora haja um conflito de pressupostos ontológicos quanto ao entendimento sobre a noção de "natureza", o "efeito pragmático" de "proteger a urihi" e "preservar o meio ambiente" parece ser o mesmo. Nesse sentido, as ontologias multinaturalistas e as naturalistas "são vastamente diferentes nas entidades que pressupõem; mas elas podem ser confrontadas pragmaticamente" (Almeida, 2013, p. 20).

Como foi discutido, na elaboração do Projeto Yaripo há mais de um entendimento quanto aos espaços destinados ao ecoturismo, que são ontologicamente conflitantes e cujas relações são marcadas por "equivocidades”. Entretanto, conforme Viveiros de Castro (2015), mesmo os equívocos não podem ser equivalentes em palcos de comunicação estabelecidos a partir de linguagens diferentes. Como alertou o autor, “[...] se o equívoco não é erro, ilusão ou mentira, mas a forma mesma da positividade relacional da diferença, seu oposto não é a verdade, mas o unívoco, enquanto pretensão à existência de um sentido único e transcendente" (idem, 2015, p. 93). Portanto, aqui também não há um sentido único nos enunciados "proteger a urihi" e "preservar a natureza". Em suma, sigo a hipótese de que se a proteção da biodiversidade - visada pela legislação ambientalista - é garantida pelo propósito yanonami do cuidado de uma rede de relações "cosmopolíticas", e vice-versa, esse suposto efeito pragmático único é, na verdade, uma equivocidade por excelência. Assim, o propósito de "proteção à floresta" emerge sob uma condição de "mais que um e menos que muitos" (de la Cadena, 2015): os modos de conceitualizar e se relacionar com o território se conectam pragmaticamente, mas não se tornam o mesmo; se sobrepõem e, ao mesmo tempo, permanecem distintos. Em suma, proteger a floresta é, a um só tempo, cuidar de uma rede de relações cosmopolíticas e preservar ecossistemas.

\section{Considerações finais}

O envolvimento de povos indígenas com o turismo é um assunto relativamente novo para a Antropologia, seja no Brasil ou em outras paisagens latino-americanas (e.g. Grünewald, 1999; de la Cadena, 2015). Além disso, o arranjo compreendido pelo Projeto Yaripo é, de certo modo, inédito, uma vez que a prática da atividade em território indígena só foi regulamentada pela FUNAI no ano de 2015. Nesse caso, vimos que, para os Yanonami, o projeto não possui somente uma motivação monetária, mas é também um meio de reivindicação de direitos e de maior fiscalização territorial. O projeto também é, para os moradores de Maturacá, um caminho para a amenização de antigos conflitos, sejam eles internos às comunidades - ausência de repartição dos benefícios econômicos oriundos do turismo clandestino - ou entre a AYRCA e as instituições fiscalizadoras do PARNA e da 
TI - relativos à entrada de visitantes ilegais e à falta de diretrizes jurídicas para a realização do turismo na área.

Embora a visitação ao Yaripo não tenha iniciado, a elaboração da proposta já "conecta parcialmente" (Strathern, 2004) diferentes mundos pautados por ontologias distintas. Nesse sentido, me parece que o desenvolvimento de projetos como esse, a partir dos caminhos conduzidos pela PNGATI e pela IN 03/2015 da FUNAI, podem aflorar como cenários bastante pertinentes à Antropologia, pois compreendem situações etnográficas nas quais a comunicação entre indígenas e instituições externas (estatais ou não) é intensificada e, assim, os diferentes discursos passam a emergir e afetar uns aos outros. A novidade aqui consiste no fato dos Yanonami fazerem de um projeto de turismo algo mais que uma fonte de renda: para eles, o Projeto Yaripo é também um meio de combater o garimpo e cuidar de uma rede de relações cosmopolíticas que constituem sua socialidade, uma vez que parte das trilhas que leva ao Pico da Neblina é também usada por garimpeiros ilegais.

O intuito aqui foi sugerir que há mais de um entendimento quanto aos espaços destinados ao ecoturismo no Projeto Yaripo. Ademais, como sugeriu Albert (2002), o interessante é notar como os Yanonami se apropriam estrategicamente de conceitos do discurso ambientalista e os colocam em favor de suas reivindicações e do combate à mineração ilegal. Em um movimento de "ida e volta" (Carneiro da Cunha, 2017), categorias como "natureza" e "meio ambiente" eram e continuam a ser transformadas por meus interlocutores, de modo a abarcar toda uma trama cosmopolítica compreendida pela ideia de urihi: "proteger a floresta" também é, para os Yanonami, uma forma de assegurar seu modo de habitar no mundo. 


\section{Referências}

ALBERT, Bruce. Temps du sang, temps des cendres: representation de la maladie, système rituel et espace politique chez les Yanomami du sud-est (Amazonie bresilienne). Tese (Doutorado em Antropologia Social) - Universite de Paris X, Paris, 1985.

ALBERT, Bruce. A fumaça do metal: história e representações do contato entre os Yanomami. Anuário Antropológico, n. 89, p. 151-189, 1992 [1988].

ALBERT, Bruce. O ouro canibal e a queda do céu: uma crítica xamânica da economia política da natureza (Yanomami) . In: ALBERT, Bruce; RAMOS, Alcida (Eds.). Pacificando o Branco: cosmologias do contato no Norte-Amazônico. São Paulo: Editora UNESP, 2002 [1995]. p. 239-274.

ALBERT, Bruce. Yanomami: retour sur image(s). Fondation Cartier: trente ans pour l'art contemporain, n. 2, p. 237-248, 2014.

ALBERT, Bruce; LE TORNEAU, François-Michel. Florestas Nacionais na Terra Indígena Yanomami - Um cavalo de Tróia ambiental? . In: RICARDO, Fany (Ed.). Terras Indígenas \& Unidades de Conservação da natureza: o desafio das sobreposições. São Paulo: Instituto Socioambiental, 2004. p. 372-383.

ALÈS, Catherine. Violence et ordre social dans une société amazonienne. Etudes Rurales, v. 95, n. 96, p. 89-114, 1984.

ALÈS, Catherine. Croniques des temps ordinaires: corésidence et fission yanomami. L'Homme, n. 113, p. 73-101, 1990.

ALÈS, Catherine. Tierras sagradas, territorios amenazados: los Yanomami más allá de su doble. In: CARILLO, A.; PEREA, M. (Eds.). Amazonas: modernidad en tradición. Caracas: GTZ-CAIAH-Sada-Amazonas, 1995. p. 205-225.

ALMEIDA, Mauro W. Barbosa de. Caipora e outros conflitos ontológicos.R@U: Revista de Antropologia da UFSCar, v. 5, n. 1, p. 7-28, 2013.

ANDRELLO, Geraldo. Cidade do índio: transformações e cotidiano em lauaretê. São Paulo: Editora UNESP/ISA/NuTI, 2006.

CARNEIRO DA CUNHA, Manuela. Pontos de vista sobre a floresta amazônica: xamanismo e tradução. Mana, v. 4, n. 1, p. 7-22, 1998.

CARNEIRO DA CUNHA, Manuela. Cultura com aspas e outros ensaios. São Paulo: UBU, 2017 [2009].

CARNEIRO DA CUNHA, Manuela; ALMEIDA, Mauro W. Barbosa de. Populações tradicionais e conservação ambiental. In: CARNEIRO DA CUNHA, Manuela Carneiro da Cunha. Cultura com aspas e outros ensaios. São Paulo: UBU, 2017 [2009]. p. 267-292.

CHIAPPINO, Jean. La cura chamánica Yanomami y su eficacia. In: ALÈS, Catherine; CHIAPPINO, Jean (Eds.). Caminos cruzados: ensayos en antropología social, etnoecología y etnoeducación. Mérida: IDR Editions/ULA-GRIAL, 2003. p. 253-290.

CHIAPPINO, Jean. Territorio y constitución de la persona Yanomami: una cartografía sagrada. In: PACHECO, L. Meneses; GORDONES, G.; CLARAC, J. (Eds.). Lecturas Antropológicas de Venezuela. Caracas: Museo Arqueológico-ULA, 2007. p. 373-378.

COUTINHO JÚNIOR, Walter. Yaripo: turismo, garimpo e agências do Estado na terra indígena Yanomami e no parque nacional Pico da Neblina. Inquéritos Civis Públicos $\mathrm{n}^{\circ}$ 1.13.000.000686/2003-86 e n 1.13.000.000692/2006-86. Manaus: Ministério Público Federal, Procuradoria da República no Amazonas, 2013.

DE LA CADENA, Marisol. Earth beings: ecologies of practice across Andean Worlds. 
Leon Terci Goulart

Durham: Duke University Press, 2015.

DESCOLA, Philippe. Societies of nature and the nature of society. In: KUPER, Adam (Ed.). Conceptualizing society. Londres: Routledge, 1992. p. 107-126.

DESCOLA, Philippe. Beyond nature and culture. Proceedings of the British Academy, n. 139, p. 137-155, 2006.

FAUSTO, Carlos. Donos demais: maestria e domínio na Amazônia. Mana, v. 14, n. 2, p. 329-366, 2008.

FERREIRA, Maryelle I. M. Mulheres Kumirãyõma: uma etnografia da criação da Associação de Mulheres Yanomami. Dissertação (Mestrado em Antropologia Social) -Universidade Federal do Amazonas, Manaus, 2017.

GOULART, Leon Terci. Os Yanonami e o Projeto Yaripo: transformações e turismo em Maturacá. Dissertação (Mestrado em Antropologia Social) - Universidade Federal de São Carlos, São Carlos, 2020.

GRÜNEWALD, Rodrigo de Azeredo. Os "Índios do Descobrimento": tradição e turismo. Tese (Doutorado em Antropologia Social) - Universidade Federal do Rio de Janeiro, Rio de Janeiro, 1999.

HARAWAY, Donna J. Manifesto ciborgue: ciência, tecnologia e feminismo-socialista no final do século XX. In: TADEU, Tomaz (Ed.). Antropologia do ciborgue: as vertigens do pós-humano. Belo Horizonte: Autêntica, 2009 [1991]. p. 33-118.

INGOLD, Tim. The perception of the environment: essays on livelihood, dwelling and skill. Londres: Routledge, 2000.

JOKIC, Zeljko. Cosmo-genesis or transformation of the Human Body into a Cosmic Body in Yanomami Shamanistic Initiation. Shaman, v. 14, n. 1, p. 19-44, 2006.

JOKIC, Zeljko. Yanomami Shamanic Initiation: the meaning of death and postmortem consciousness in transformation. Anthropology of Consciousness, v. 19, n. 1, p. 33-59. 2008.

KELLY, Jose Antonio. Relations within the Health System among the Yanomami in the Upper Orinoco, Venezuela. Tese (Doutorado em Antropologia Social) - University of Cambridge, Cambridge, 2003.

KELLY, Jose Antonio. Notas para uma teoria do “virar branco". Mana, v. 11, n. 1, p. 201234, 2005.

KOPENAWA, Davi; ALBERT, Bruce. A queda do céu: palavras de um xamã yanomami. São Paulo: Companhia das Letras, 2015 [2010].

LATOUR, Bruno. Jamais fomos modernos. Rio de Janeiro: Editora 34, 1994 [1991].

LIMA, Tânia Stolze. O dois e seu múltiplo: reflexões sobre o perspectivismo em uma cosmologia Tupi. Mana, v. 2, n. 2, p. 21-47, 1996.

LIZOT, Jacques. Diccionario Enciclopédico de la Lengua Yãnomãmi. Caracas: Vicariato Apostólico de Puerto Ayacucho, 2004.

MENEZES, Gustavo Hamilton. Yanomami na encruzilhada da conquista: contato e transformação na fronteira amazônica. Tese (Doutorado em Antropologia Social) Universidade de Brasília, Brasília, 2010.

PLANO DE VISITAÇÃO YARIPO, 2017. Disponível em: https://www.socioambiental.org/ sites/blog.socioambiental.org/files/plano_de_visitacao_versao_final_julho2017. pdf. Acesso em: 25 dez. 2018.

RAMOS, Alcida Rita. Memórias Sanumá: espaço e tempo em uma sociedade Yanomami. 
Leon Terci Goulart

São Paulo: Marco Zero, 1990.

RICARDO, Fany (Org.). Terras Indígenas \& Unidades de Conservação da natureza: o desafio das sobreposições. São Paulo: Instituto Socioambiental, 2004.

RICARDO, Fany; ANDRELLO, Geraldo. Muitas "providências”, poucas soluções. In: RICARDO, Fany (Ed.). Terras Indígenas \& Unidades de Conservação da natureza: o desafio das sobreposições. São Paulo: Instituto Socioambiental, 2004. p. 363-367.

SMILJANIC, Maria Inês. Os enviados de Dom Bosco entre os Masiripiwëiteri. O impacto missionário sobre o sistema social e cultural dos Yanomami ocidentais. Journal de la Société des Américanistes, n. 88, 2002. p. 137-158.

SMILJANIC, Maria Inês. À sombra do Pico da Neblina. In: RICARDO, Fany (Ed.). Terras Indígenas \& Unidades de Conservação da natureza: o desafio das sobreposições. São Paulo: Instituto Socioambiental, 2004. p. 368-371.

STRATHERN, Marilyn. Partial connections. Nova York: Altamira, 2004.

SZTUTMAN, Renato. Sobre a ação xamânica. In: GALLOIS, Dominique Tilkin (Ed.). Rede de relações nas Guianas. São Paulo: Associação Editorial Humanitas, 2005. p. 151226.

TAYLOR, Kenneth I. Sanuma (Yanoama) Food Prohibitions: the multiple classification of society and fauna. Tese (Doutorado em Antropologia Social) - University of Wisconsin, Madison, 1972.

TAYLOR, Kenneth I. Body and spirit among the Sanuma (Yanoama) of north Brazil. In: BROWMAN, David L.; SCHARWZ, Ronald A. (Eds.). Spirits, shamans and stars: perspectives from south America. Nova Iorque: Mouton Publishers, 1979. p. 201-222.

TAYLOR, Kenneth I. A Geografia dos Espíritos: o xamanismo entre os Yanomami setentrionais. In: LANGDON, E. Jean Matteson (Ed.). Xamanismo no Brasil: novas perspectivas. Florianópolis: Editora da UFSC, 1996. p. 117-151.

VALENTIM, Marco Antonio. Extramundanidade e sobrenatureza: ensaios de ontologia infundamental. Florianópolis: Cultura e Barbárie, 2018.

VIVEIROS DE CASTRO, Eduardo. Os pronomes cosmológicos e o perspectivismo ameríndio. Mana, v. 2, n. 2, p. 115-144, 1996.

VIVEIROS DE CASTRO, Eduardo. Perspectival anthropology and the method of controlled equivocation. Tipiti, v. 2, n. 1, p. 3-22, 2004a.

VIVEIROS DE CASTRO, Eduardo. Exchanging perspectives: the transformation of objects into subjects in Amerindian ontologies. Common Knowledge, v. 10, n. 3, p. 463-484, 2004b.

VIVEIROS DE CASTRO, Eduardo. A floresta de cristais: notas sobre a ontologia dos espíritos amazônicos. Cadernos de Campo, v. 14, n. 15, p. 319-338, 2006.

VIVEIROS DE CASTRO, Eduardo. Metafísicas canibais. São Paulo: Cosac Naify, 2015 [2009].

VIVEIROS DE CASTRO, Eduardo. A inconstância da alma selvagem e outros ensaios de Antropologia. São Paulo: Ubu, 2017[2002].

WAGNER, Roy. The fractal person. In: GODELIER, Maurice; STRATHERN, Marilyn (Eds.). Big men and great men: personifications of power in Melanesia. Cambridge: Cambridge University Press, 1991. p. 159-173. 